\title{
Evaluation of Lipid Profile in the Smokers and Non-Smokers
}

\author{
Vachan Mehta ${ }^{\circledR 1}$, Darshak Salat ${ }^{\circledR 2}$ \\ ${ }^{1}$ Associate Professor, Department of Medicine, Gujarat Adani Institute of Medical Science, Bhuj, Kutch, Gujarat, India, ${ }^{2}$ Assistant Professor, Department of Medicine, \\ Gujarat Adani Institute of Medical Science, Bhuj, Kutch, Gujarat, India.
}

\section{Abstract}

Background: Cigarette smoking leads to increased serum level of total cholesterol, LDL cholesterol, Triglyceride levels and decreased level of anti atherogenic HDL cholesterol. Many studies have shown a dose-dependent relationship between smoking and lipoprotein profile. Hence this study was-taken up to know the lipoprotein pattern in healthy young smokers. Subjects and Methods: Total of hundered healthy smokers and fifty healthy non smokers were included in the study. All the smokers' subjects were divided in two groups as per the severity of the habit of smoking. Group 1: all those who smoke upto 10 cigarette per day, Group 2: all those who smokemore than 10 cigarette per day. Results: In our study, the mean serum cholesterol of smokers is $205.9 \pm 26.1$ and that of non-smokers is $165.4 \pm 15.2$ which is statistically significant Mean HDL-cholesterol is $34.20 \pm 4.0$ in smokers and $38.40 \pm 6.4$ in non-smokers, which is statistically significant. Mean LDL-cholesterol is 155.8 \pm 29.30 in smokers and $136.70 \pm 14.45$ in nonsmokers which is statistically significant. Mean Triglyceride level in smokers is $163.28 \pm 38.7$ and in non-smokers it is $116.72 \pm 23.3$ which is statistically significant. Conclusion: The mean serum lipid values were significantly higher in smokers except HDL-C which were significantly decreased, as compared to non smokers. There is a linear increase in the levels of serum lipids except HDL-C which shows decrease in the levels with the duration and severity of smoking.

Keywords: Lipid Profile, Smokers, Non-Smokers, Nicotine

Corresponding Author: Darshak Salat, Assistant Professor, Department of Medicine, Gujarat Adani Institute of Medical Science, Bhuj, Kutch, Gujarat, India.

E-mail: dpsalat@gmail.com

Received: 6 January 2020

Revised: 11 February 2020

Accepted: 21 February 2020

Published: 18 May 2020

\section{Introduction}

Smoking of tobacco is a vice that has been practiced by people all over the world cutting across national and social barriers. The increasing habit of smoking has resulted in a highincidence of tobacco related diseases all over the developing world. ${ }^{[1]}$ Smoking in different forms is a major risk factor for atherosclerosis and coronary heart disease. There is a dose response relationship between the number of cigarettes/bidis smoked and cardiovascular morbidity and mortality. ${ }^{[2]}$

The greatest responsibility of physicians is to combat smoking, both through their advice to patients and through their influence- in the community through health education. ${ }^{[3]}$ The addictive effects of nicotine account for most of this persistent personal and public health dilemma. Recognition of tobacco use as an addiction and of nicotine as the addictive drug is essential for effective patient management. ${ }^{[4]}$

Smokers regulate their nicotine dose to obtain desired effects: these include both intrinsic positive effects, such as pleasure and enhanced performance and avoidance of the withdrawal syndrome. ${ }^{[5]}$ This syndrome is characterised by anger, anxiety, difficulty in concentration, impatience, restlessness and craving for tobacco products. Most of these symptoms peak in 1-2 days and, return to base line within 34weeks of quitting. ${ }^{[6]}$

These silent effects begin immediately and greatly which increase the risk for heart disease and stroke. Cigarette smoking leads to increased serum level of total cholesterol, LDL cholesterol, Triglyceride levels and decreased level of anti atherogenic HDL cholesterol. ${ }^{[7]}$ Many studies have shown a dose-dependent relationship between smoking and lipoprotein profile. Hence this study was-taken up to know the lipoprotein pattern in healthy young smokers.

\section{Subjects and Methods}

Total of hundered healthy smokers and fifty healthy nonsmokers were included in the study. All the included subjects were of mid socio economic status. The age group were they belong was from $25-40$ years. Persons abusing alcohol, ex-smokers 
and having risk factors like diabetes mellitus, hypertension, and obesity were excluded from the study. Patients on drugs like beta-blockers and thiazide diuretics which were found to interfere with lipid profile were also excluded from the study.

All the smokers' subjects were divided in two groups as per the severity of the habit of smoking. Group 1: all those who smoke upto 10 cigarette per day, Group 2: all those who smoke More than 10 cigarettes per day. After a detailed history followed by clinical examination, routine investigations like $\mathrm{Hb}, \mathrm{TC}, \mathrm{DC}$, ESR, FBS and Serum creatinine were done in all the cases.

Instructions were given to the smokers as well as controls to take a normal diet for 3 days before the lipid profile estimation was done, since food intake few hours before study would have impaired the results. Blood samples were obtained following an overnight fasting. Samples were withdrawn from a cubital vein into blood tubes. The serum was then separated from the cells by centrifugation at $3000 \mathrm{r} / \mathrm{min}$ for $10 \mathrm{~min}$ and immediately stored on ice at $4^{\circ} \mathrm{C}$. Lipid was estimated which included total serum cholesterol, HDL-cholesterol, LDLcholesterol and serum triglycerides.

\section{Results}

The result of the present study were arranged into tables showing each variable. They were compared with those of control group. The variables were total cholesterol, HDL-cholesterol, LDL-cholesterol, triglycerides, number of cigarettes smoked per day. Total of 100 smokers and 50 non smokers participated in the study. Both the smokers and nonsmokers were comparable in terms of age, weight, body mass index and dietary habits.

In our study, the mean serum cholesterol of smokers is 205.9 \pm 26.1 and that of non-smokers is $165.4 \pm 15.2$ which is statistically significant Mean HDL-cholesterol is $34.20 \pm$ 4.0 in smokers and $38.40 \pm 6.4$ in non-smokers, which is statistically significant. Mean LDL-cholesterol is $155.8 \pm$ 29.30 in smokers and $136.70 \pm 14.45$ in nonsmokers which is statistically significant. Mean Triglyceride level in smokers is $163.28 \pm 38.7$ and in non-smokers it is $116.72 \pm 23.3$ which is statistically significant. [Table 1]

There is a statistically significant rise in Total serum cholesterol as the severity of smoking increased showing $\mathrm{p}$ value $(<0.01)$ and also in HDL-cholesterol which showed significant decrease as the severity of smoking increased. But the LDL cholesterol and the triglyceride levels though showed increase in levels the ' $p$ ' values were not statistically significant. [Table 2]

\section{Discussion}

Cigarette smoking is one of the leading causes of preventable morbidity and mortality that usually starts in adolescence and

\begin{tabular}{|c|c|c|c|}
\hline Parameter & Smokers & $\begin{array}{l}\text { Non smok- } \\
\text { ers }\end{array}$ & P value \\
\hline $\begin{array}{l}\text { Total } \\
\text { cholesterol }\end{array}$ & $\begin{array}{ll}205.9 & \pm \\
26.1 & \end{array}$ & $165.4 \pm 15.2$ & $<0.001$ \\
\hline $\begin{array}{l}\text { HDL } \\
\text { choles- } \\
\text { terol }\end{array}$ & $34.20 \pm 4.0$ & $38.40 \pm 6.4$ & $<0.001$ \\
\hline $\begin{array}{l}\text { LDL choles- } \\
\text { terol }\end{array}$ & $\begin{array}{l}155.8 \\
29.30\end{array}$ & $\begin{array}{l}136.70 \\
14.45\end{array}$ & $<0.001$ \\
\hline Triglycerides & $\begin{array}{l}161.2 \\
35.3\end{array}$ & $\begin{array}{l}110.35 \quad \pm \\
20.2\end{array}$ & $<0.001$ \\
\hline
\end{tabular}

Table 2: Lipid profile in smokers and non smokers according to the severity of smoking

\begin{tabular}{|c|c|c|c|}
\hline Parameter & $\begin{array}{lll}1-10 & -10 \\
\text { cig/day } & \end{array}$ & $\begin{array}{l}\text { Non smok- } \\
\text { ers }\end{array}$ & P value \\
\hline $\begin{array}{l}\text { Total choles- } \\
\text { terol }\end{array}$ & $\begin{array}{l}195.12 \pm \\
21.5\end{array}$ & $\begin{array}{l}212.4 \quad \pm \\
35.2\end{array}$ & $<0.001$ \\
\hline $\begin{array}{l}\text { HDL choles- } \\
\text { terol }\end{array}$ & $34.20 \pm 4.0$ & $38 \pm 5.8$ & $<0.001$ \\
\hline $\begin{array}{l}\text { LDL choles- } \\
\text { terol }\end{array}$ & $\begin{array}{l}159.2 \\
18.20\end{array}$ & $\begin{array}{l}170.60 \pm \\
45.42\end{array}$ & NS \\
\hline Triglycerides & $\begin{array}{l}164.12 \\
32.3\end{array}$ & $\begin{array}{l}181.31 \pm \\
42.2\end{array}$ & NS \\
\hline
\end{tabular}

NS (Nothing Significant)

continues into adult life. Cigarette smoking is the single most important preventable cause of illness and death. There is an increasing incidence of mortality due to cigarette smoking as compared to other causes of death like alcohol, addictive drugs and suicides. ${ }^{[8]}$

Cigarette smokers have a high risk of coronary Heart disease than nonsmokers. Several possible explanations have been offered for this association including altered blood coagulability, decreased fibrinolysis, impaired integrity of the arterial wall, and changes in blood lipid and lipoprotein concentrations. In the industrialized world, $50 \%$ of the deaths are attributed to atherosclerosis and its complications. ${ }^{[9]}$

Various mechanisms leading to lipid alteration by smoking are: (a) nicotine stimulates sympathetic adrenal system leading to increase secretion of catecholamines resulting in increased lipolysis and increased concentration of plasma free fatty acids (FFA) which further result in increased secretion of hepatic FFAs and hepatic triglycerides along with VLDL in the blood stream (b) Fall in oestrogen levels occurs due to smoking which further leads to decreased HDL; (c) Presence of hyperinsulinaemia in smokers leads to increased cholesterol, LDL and TG due to decreased activity of 
lipoprotein lipase. ${ }^{[10,11]}$

In the 25 - 35 year age group comprising 100 smokers; the mean total cholesterol was $205.9+26.1 \mathrm{mg} / \mathrm{dl}$ while in the control group comprising 50 persons; the total mean cholesterol was $165.4+15.2 \mathrm{mg} / \mathrm{dl}$. This was a phenomenal difference. This data is in accordance with other studies done by various reserachers. Of the 100 smokers (25-40 year age group), the mean value of HDL cholesterol stood at $34.20+$ $4.0 \mathrm{mg} / \mathrm{dl}$, while in the control group it is $38.40+6.4 \mathrm{mg} / \mathrm{dl}$. The inference is clear. HDL-values decreased significantly with smoking and these persons are at a higher risk for coronary Heart disease.

\section{Conclusion}

The mean serum lipid values were significantly higher in smokers except HDL-C which were significantly decreased, as compared to non smokers. There is a linear increase in the levels of serum lipids except HDL-C which shows decrease in the levels with the duration and severity of smoking.

\section{References}

1. Kanavos P. The rising burden of cancer in the developing world. Ann Oncol. 2006;17:815-823. Available from: https: //dx.doi.org/10.1093/annonc/mdl983.

2. Buttar HS, Li T, Ravi N. Prevention of cardiovascular diseases: Role of exercise, dietary interventions, obesity and smoking cessation. Exp Clin Cardiol. 2005;10:229-229.

3. Anda RF. Are physicians advising smokers to quit? The patient's perspective. JAMA-J Am Med Asso. 1987;257(14):1916-1919. Available from: https://dx.doi.org/ 10.1001/jama.257.14.1916.

4. Killen JD, Fortmann SP, Schatzberg AF, Arredondo C, Murphy G, Hayward C. Extended cognitive behavior therapy for cigarette smoking cessation. Addiction. 2008;103(8):13811390 .
5. Little HJ. Behavioral mechanisms underlying the link between smoking and drinking. Alcohol Res Health. 2004;24:215-224.

6. Ch SR, Y ES. The effect of chronic tobacco smoking and chewing on the lipid profile. J Clin Diagn Res. 2013;7(1):3134. Available from: https://dx.doi.org/10.7860/JCDR/2012/ 5086.2663.

7. Granot E, Kohen R. Oxidative stress in childhood - in health and disease states. Clin Nutr. 2004;23(1):3-11. Available from: https://dx.doi.org/10.1016/s0261-5614(03)00097-9.

8. Mokdad AH, Marks JS, Stroup DF, Gerberding JL. Actual causes of death in the United States, 2000. JAMA. 2004;291(10):1238-1245. Available from: https://dx.doi.org/ 10.1001/jama.291.10.1238.

9. O'Toole TE, Conklin DJ, Bhatnagar A. Environmental Risk Factors for Heart Disease. Rev Environ Health. 2008;23(3):167-202. Available from: https://dx.doi.org/10. 1515/reveh.2008.23.3.167.

10. Kilaru S, Frangos SG, Chen AH, Gortler D, Dhadwal AK, Araim $\mathrm{O}$, et al. Nicotine: a review of its role in atherosclerosis 1 1No competing interests declared. J Am Coll Surg. 2001;193(5):538-546. Available from: https://dx.doi.org/10. 1016/s1072-7515(01)01059-6.

11. Hulea SA, Olinescu R, Nitã S, Crocnan D, Kummerow FA. Cigarette smoking causes biochemical changes in blood that are suggestive of oxidative stress: a case-control study. J Environ Pathol Toxicol Oncol. 1995;14(3-4):173-80.

Copyright: (C) the author(s), 2020. It is an open-access article distributed under the terms of the Creative Commons Attribution License (CC BY 4.0), which permits authors to retain ownership of the copyright for their content, and allow anyone to download, reuse, reprint, modify, distribute and/or copy the content as long as the original authors and source are cited.

How to cite this article: Mehta V, Salat D. Evaluation of Lipid Profile in the Smokers and Non-Smokers. Acad. J Med. 2020; 3(1):1-3.

DOI: dx.doi.org/10.47008/ajm.2020.3.1.1

Source of Support: Nil, Conflict of Interest: None declared. 